\title{
Diversity of hydrolase-producing halophilic bacteria and evaluation of their enzymatic activities in submerged cultures
}

\author{
Leila Batsoule Drissi Kaitouni ${ }^{1}$, Jaouad Anissi ${ }^{1,2}$ (D) Khalid Sendide ${ }^{3}$ (D) and Mohammed El Hassouni ${ }^{*^{*}}$ (D)
}

\begin{abstract}
Purpose: In this work, we assessed the diversity of culturable halophilic bacteria that produce hydrolytic enzymes from both natural and artificial hypersaline regions in the pre-Rif region of Morocco.

Methods: Bacteria were isolated from three hypersaline sites, in solid medium supplemented with various salt concentrations ranging from 0 to $330 \mathrm{~g} / \mathrm{L}$. Physical and chemical characteristics of samples from the isolation site were determined to suggest eventual correlations with the occurrence of the halophilic bacteria. Assays on enzymatic activities were performed in submerged cultures in the presence of various salt concentrations and appropriate substrates.

Results: Out of a collection of 227 halophilic bacteria, four halophilic groups were established as slightly halophilic, moderately halophilic, halotolerant, or extremely halophilic, with a predominance of halophilic bacteria in the natural hypersaline sites compared to the artificial one. Within this collection, 189 strains showed important hydrolytic activities in submerged cultures with enzymatic activities up to $76 \mathrm{U} / \mathrm{mg}$. Strain characterization and identification was based on phenotypic and molecular traits and allowed the identification of at least 26 genera including Bacillus, Chthonibacter, Mariniabilia, Halobacillus, Salinococcus, Cerasicoccus, Ulvibacter, Halorubrum, Jeatgalicoccus, Brevibacterium, Sanguibacter, Shewanella, Exiguobacterium, Gemella, and Planomicrobium.

Conclusion: Data from this study give insights about the origin and the occurrence of halophilic bacteria in natural hypersaline environments compared to artificial hypersaline sites. The occurrence of halophilic hydrolase enzymes from halophilic bacteria gives insights to different applications in biotechnology, thanks to their ability to produce adaptive enzymes and survival strategies to overcome harsh conditions.
\end{abstract}

Keywords: Hypersaline environment, Halophilic bacteria, Hydrolase enzymes

\section{Introduction}

Hydrolases (EC 3 in Enzyme Commission classification) are ubiquitous in nature and are widely distributed among microorganisms, in particular within bacteria (Quax 2006) and fungi (Demain and Adrio 2008). These enzymes are critical for biomass and complex macromolecule modification and breakdown at both environmental level, where

\footnotetext{
* Correspondence: mohammed.elhassouni@usmba.ac.ma

${ }^{1}$ Faculty of Sciences Dhar El Mahraz, Laboratory of Biotechnology, Environment, Agri-Food and Health, Sidi Mohamed Ben Abdellah University, Fez, Morocco

Full list of author information is available at the end of the article
}

they contribute to most of the geochemical processes, and at the industrial level as critical ingredients in most of the food, agricultural, and pharmaceutical industries (Singh et al. 2016). The requirements and the modus operandi of the abovementioned industries made the urge to explore other sources of enzymes, among the extremophile microorganisms. Recently, the halophilic bacteria gain interest from their capacity to adapt to very high salt concentrations; a halophilic organism needs imperatively the presence of moderate and high salt concentrations, and the halotolerant have no need of salt for their growth but can grow in the presence of very high salt concentrations

(c) The Author(s). 2020 Open Access This article is licensed under a Creative Commons Attribution 4.0 International License, which permits use, sharing, adaptation, distribution and reproduction in any medium or format, as long as you give appropriate credit to the original author(s) and the source, provide a link to the Creative Commons licence, and indicate if changes were made. The images or other third party material in this article are included in the article's Creative Commons licence, unless indicated otherwise in a credit line to the material. If material is not included in the article's Creative Commons licence and your intended use is not permitted by statutory regulation or exceeds the permitted use, you will need to obtain permission directly from the copyright holder. To view a copy of this licence, visit http://creativecommons.org/licenses/by/4.0/. 
(Torregrosa-Crespo et al. 2017). Halophilic bacteria have been increasingly studied for their biotechnological potential to produce enzymes that are stable and active at alkaline $\mathrm{pH}$, high temperature, and high salt concentrations (Di Donato et al. 2018). These multifaceted attributes are attractive in diverse industries (Delgado-Garcia et al. 2012), such as in fermented food, in textile, in pharmaceutical, in cosmetic, and in leather industries (De Lourdes et al. 2013). Such requirement of salts for growth is decidedly required for the functioning of most of the metabolic pathways orchestrated by enzymes and thus make them suitable for use in industrial processes that include high salts concentrations (Liu et al. 2018).

In Morocco, several hypersaline environments were described (Bouchotroch et al. 1999; Berrada et al. 2012). Among them, the pre-Rif region is characterized by the abundance of Triassic outcrops that form a lithologic complex of ophites and gypso-salt clay. The main areas are those located in the region of Fez and Taza, where Triassic diapirs are scattered, frequently associated with salt ponds and gypsum quarries of marine origin, and mined in traditional settling ponds (Michard et al. 2014). Hypersaline biotopes such as salt mines and saline lakes are typical examples of extreme environments that house an omnifarious biodiversity of halophilic bacteria. In this kind of extreme environments, studies generally reveal the predominance of genera of the domain bacteria, including Bacillus, Halobacillus, Virgibacillus, Oceanobacillus, Staphylococcus, Pseudomonas, Idiomarina, Halomonas, Marinobacter, Thalassobacillus, Piscibacillus, Gracilibacillus, Salicola, Salinicoccus, Flavobacterium, Exiguobacterium, Paracoccus, Chromobacterium, Kushneria, Cobetia, Marinococcus, Nesterenkonia, and Tetragenococcus (Babavalian et al. 2014; Al-Rubaye et al. 2017;Dumorné 2018).

In the present work, we assessed the diversity of cultivable halophilic bacteria with hydrolytic enzymes activity, namely amylase, pectinase, protease, inulinase, and cellulase, which were chosen based on their potential utilization in multiple industrial processes, as they are characterized by their stability at high salt concentrations (Lima and Porto 2016; Dumorné 2018). The halophilic and halotolerant bacteria were collected from three hypersaline sites: the Mount Zalagh salt mine (site 1) and, two salt marshes, Meknassa (site 2) and Bab Merzouka (site 3), located in the pre-Rif region of Morocco. Phenotypic/phylogenetics traits as well as data related to their hydrolytic activities were emphasized in order to get insight about bacterial occurrence in such hypersaline environments and to explore the hydrolytic activities of such bacteria.

\section{Material and methods}

Sampling, physicochemical analysis, and bacteria isolation Aqueous and solid samples were collected from sites with the following GPS coordinates: $34^{\circ} 7^{\prime} 34.95^{\prime \prime} \mathrm{N} 4^{\circ}$ $54^{\prime} 51.67^{\prime \prime} \mathrm{W}, 34^{\circ} 15^{\prime} 50.21^{\prime \prime} \mathrm{N} 4^{\circ} 3^{\prime} 26.46^{\prime \prime} \mathrm{W}$, and $34^{\circ}$ $13^{\prime} 17.29^{\prime \prime} \mathrm{N} 4^{\circ} 6^{\prime} 24.66^{\prime \prime} \mathrm{W}$, for site 1 (salt mine), site 2 , and site 3 (salt marshes), respectively. A map and pictures of sampling sites are shown the Fig. S1 and S2 (supplementary material). Aqueous samples from all the three sites were collected from the settling pond; the mud represents the mixture of water and soil of the edge of these settling pond and the soil represents the dry part around the basin or settling ponds; bare soil with no vegetation is often covered with salt crystals; it is at 2 $\mathrm{m}$ of the settling pound that vegetation begin, as showed in the of the supplementary material. Samples were aseptically collected in sterile plastic containers and analyzed within the next $10 \mathrm{~h}$. Physical and chemical parameters such as $\mathrm{pH}, \mathrm{T}^{\circ} \mathrm{C}$, and electrical conductivity (EC) were also recorded at the time of sampling. The mineral profile of each site was analyzed by Inductively coupled plasma atomic emission spectroscopy (ICPAES). The organic matter, moisture, chemical oxygen demand $(\mathrm{COD})$, biological oxygen demand $\left(\mathrm{BOD}_{5}\right)$, total dissolved salts, and total mineral matter were also measured (Rodier et al. 2009; Graf-Rosenfellner et al. 2016). Bacteria were isolated from aqueous and re-suspended solid samples using the serial dilution and plating methods, and cells were spread out on modified Luria Bertani (LB) agar medium (composition per liter: tryptone $10 \mathrm{~g}$, yeast extract $5 \mathrm{~g}$, Agar $20 \mathrm{~g}, \mathrm{pH}$ 7.2) containing different $\mathrm{NaCl}$ concentrations $(0.0$ to $330 \mathrm{~g} / \mathrm{L})$. The plates were incubated at $37{ }^{\circ} \mathrm{C}$, and the growth was monitored at 1-day intervals for $72 \mathrm{~h}$. Independent bacterial colonies with different morphologies were isolated, purified, and then stored for further use.

\section{Phenotypic and biochemical identification}

Isolates phenotypic characteristics were assessed as described by Gerhardt et al. (1994). Tests include Gram staining, motility, sporulation, catalase and oxidase activities, carbon source utilization and fermentation, and the production of hydrolase enzymes (cellulases, pectinases, amylases, inulinases, and proteases). Isolates response to $\mathrm{NaCl}$ was determined at different concentrations of $\mathrm{NaCl}$, ranging from 0.0 to $330 \mathrm{~g} / \mathrm{L}$ at $30 \mathrm{~g} / \mathrm{L}$ increment, and each strain was classified according to Ventosa and Arahal (2009) halophilic bacteria classification.

\section{$16 \mathrm{~S}$ rDNA sequencing and phylogenetic analysis}

The DNA extraction and purification was performed as follows: cells from $3 \mathrm{ml}$ cultures in LB medium were harvested at $10000 \mathrm{~g}$ for $10 \mathrm{~min}$. The pellet was resuspended in $500 \mu \mathrm{l}$ of TE buffer $(10 \mathrm{mmol} / \mathrm{L}$ Tris- $\mathrm{HCl}, 1$ $\mathrm{mmol} / \mathrm{L}$ EDTA and $\mathrm{pH} 8$ ), and then, $10 \mathrm{~g} / \mathrm{L}$ of SDS and $0.01 \mathrm{~g} / \mathrm{L}$ of proteinase-K (Sigma-France) were added. The mixture was incubated at $50{ }^{\circ} \mathrm{C}$ for $5 \mathrm{~min}$. Two volumes of ethanol were added and the mixture was 
centrifuged at $10000 \mathrm{~g}$ for $10 \mathrm{~min}$, at $4{ }^{\circ} \mathrm{C}$. The pellet was then washed with $75 \%$ ethanol, harvested, dried, and then resuspended in $100 \mu \mathrm{L}$ MilliQ water. $16 \mathrm{~S}$ rDNA amplification was carried out using universal primers, 27F (AGAGTTTGATCCTGGCTCAG) and 1392R (GGTTAC CTTGTTACGACTT). The reaction mix was prepared in a final volume of $20 \mu \mathrm{L}$ containing $4 \mu \mathrm{L}$ Taq buffer (5×), $1.2 \mu \mathrm{L}$ of $\mathrm{MgCl} 2(25 \mathrm{mmol} / \mathrm{L}), 4 \mu \mathrm{L}$ of dNTPs $(1 \mathrm{mmol} /$ L), $0.5 \mu \mathrm{L}$ of each primer $(10 \mu \mathrm{mol} / \mathrm{L}), 0.2 \mu \mathrm{L}$ of Taq polymerase $(5 \mathrm{U} / \mu \mathrm{L}), 6.6 \mu \mathrm{L}$ of pure $\mathrm{H}_{2} \mathrm{O}$, and $2 \mu \mathrm{L}$ of extracted DNA. Amplification was conducted as described by Turner et al. (1999). Sanger sequencing was performed at the Center of Innovation (USMBA, Fez-Morocco) using an ABI PRISM 3130XL Genetic Analyzer (Applied Biosystems). Preliminary identifications were performed based on sequence assembly and by search in the NCBI database. Strains were attributed to a particular genus when the sequence similarity with a strain type was at least $98 \%$ and to a given species when sequence similarity was at least $99.5 \%$. To study the phylogenetic relationship among the isolates and other homologous species, we applied the neighbor-joining (NJ) criteria, using the MEGA X software (Kumar et al. 2018). Phylogeny tests were assessed by bootstrapping with 1000 replicates; the maximum likelihood composite was used as substitution model. The obtained 16S rDNA gene fragments sequences were deposited in the NCBI database under the accession numbers MK713683 - MK713732.

\section{Qualitative and quantitative assessments of extracellular hydrolytic activities}

The isolated strains were preliminarily characterized for their qualitative enzyme production and activity on agar plates on mineral medium M9 (composition per liter: 6 g Na $2 \mathrm{HPO} 4,3 \mathrm{~g} \mathrm{KH}_{2} \mathrm{PO} 4,1 \mathrm{~g} \mathrm{NH}_{4} \mathrm{Cl}, 0.5$ g yeast extract, $0.1 \mathrm{mmol} / \mathrm{l} \mathrm{CaCl}, 1 \mathrm{mmol} / \mathrm{L} \mathrm{MgSO}_{4}, 18 \mathrm{~g}$ Agar-Agar) supplemented with a final substrate concentration of 5 $\mathrm{g} / \mathrm{L}$ and different concentrations of $\mathrm{NaCl}$ ranging from 0.0 to $330 \mathrm{~g} / \mathrm{L}$. The plates were incubated at $37^{\circ} \mathrm{C}$ for 48 $h$ except the plates for the protease activity, which were monitored for $168 \mathrm{~h}$. In such conditions, cellulase activity was determined on mineral medium M9 agar supplemented with 5 g carboxymethyl cellulose salt. After 2 days of incubation at $37{ }^{\circ} \mathrm{C}$, CMCase activity was revealed by covering the surface of the agar plate with Congo red solution $(1 \mathrm{~g} / \mathrm{L})$ for $10 \mathrm{~min}$ and then washing with a solution of $60 \mathrm{~g} / \mathrm{L} \mathrm{NaCl}$ : a yellowish surrounding zone against a red background confirmed the activity (Gohel et al. 2014). Amylase activity was qualitatively determined on minimal starch agar medium (M9 medium supplemented with $5 \mathrm{~g} / \mathrm{L}$ starch). Plates were incubated at $37{ }^{\circ} \mathrm{C}$ for 2 days, and the activity was revealed using iodine reagent $(0.01 \mathrm{~mol} / \mathrm{L} \mathrm{KI}$ solution). A positive assay occurs when a transparent zone forms around the strain colony, opposed to a dark purple background (Mishra and Behera 2008). Pectinolytic activity was determined on M9 minimal medium supplemented with $5 \mathrm{~g} / \mathrm{L}$ polygalacturonic acid at a $\mathrm{pH}$ of 8.2. After incubation at $37^{\circ} \mathrm{C}$ for 2 days, the medium surface was layered with a copper acetate solution $(75 \mathrm{~g} / \mathrm{L})$ for $10-20 \mathrm{~min}$, and then washed several times with distilled water. Positive pectinolytic activity was revealed by a clear zone around the growth colony opposed to a blue background. Inulinase activity was carried out on agar M9 minimal medium plates containing inulin at $5 \mathrm{~g} / \mathrm{L}$ as a sole carbon source. Inulinase activity was determined by appearance of transparent zone around the colony when the plate was flooded with iodine reagent and after 2 days of incubation at $37^{\circ} \mathrm{C}$ ( Li et al. 2011). Protease activity was assayed using milk agar medium (M9 medium supplemented with $5 \mathrm{~g} / \mathrm{L}$ powder milk). After 7 days of growth, clear zones around the colonies indicated positive proteolytic activity.

Extracellular hydrolytic enzymes production and activity measurements were assessed in submerged cultures (M9 mineral medium) supplemented with appropriate substrate at $5 \mathrm{~g} / \mathrm{L}$ and different concentrations of $\mathrm{NaCl}$ ranging depending on each strain's salt tolerance category: $1 \mathrm{~g} / \mathrm{L}$ for the slight halophilic and halotolerant strains, $60 \mathrm{~g} / \mathrm{L}$ for the moderately halophilic strains, and $150 \mathrm{~g} / \mathrm{L}$ for the extremely halophilic strains. The growth and enzymatic activities were monitored at $37{ }^{\circ} \mathrm{C}$ under orbital shaking at $140 \mathrm{rpm}$. After $24 \mathrm{~h}$, the supernatants were collected after centrifugation at $10,000 g$ for $10 \mathrm{~min}$ at $4{ }^{\circ} \mathrm{C}$ and used to carry out all the enzymatic tests.

The reducing units were determined for the CMCase, amylase, pectinase, and inulinase using the dinitrosalicylic acid method, $500 \mu \mathrm{l}$ of supernatants, and $500 \mu \mathrm{l}$ of the substrate buffer (sodium acetate at $\mathrm{pH} 4.8$ and $20 \mathrm{~g} / \mathrm{L}$ of the substrate). The substrates used were as follows: starch, $\mathrm{CMC}$, pectin, and inulin respectively for amylase, cellulase, pectinase, and inulinase activities. The mixtures were incubated at $50{ }^{\circ} \mathrm{C}$ for $30 \mathrm{~min}$, and after the addition of DNS reagent, the mixture was incubated at $100{ }^{\circ} \mathrm{C}$ for $5 \mathrm{~min}$. Protease activity was determined by the method of Hagihara (Hagihara 1958), using casein buffer (NaOH-Borax pH 10.0 and $6 \mathrm{~g} / \mathrm{L}$ casein). Protease assay was conducted at $37{ }^{\circ} \mathrm{C}$, $20 \mathrm{~min}$. The TCA was added, and the mixture was incubated at room temperature for $20 \mathrm{~min}$. Total protein content was determined using Bradford reagent (Bradford 1976). Bacterial growth was taken by spectrophotometry at $600 \mathrm{~nm}$. One unit of CMCase, amylase, pectinase, inulinase, and protease activities was defined as the amount of enzyme that releases $1 \mu \mathrm{mol}$ of glucose, maltose, galacturonic acid, fructose, and tyrosine per minute, respectively.

\section{Statistical analysis}

Data were expressed as means \pm standard deviation (SD) obtained from triplicate experiments, and all statistical 
analyses and data plotting were performed under $\mathrm{R}$ program version 3.5.1.

\section{Results and discussion}

Physical and chemical analysis of the sampling sites

In this study, many samples from three hypersaline sites located in the pre-Rif region in Morocco (Fig S1) were prospected for halophilic bacteria producing highly active hydrolases. As shown in Table 1, the bacterial colony count ranged from $1.2 .10^{5}$ to $3.3 .10^{6} \mathrm{CFU} / \mathrm{g}$ and from 2.2.10 $0^{5}$ to $2.25 .10^{6} \mathrm{CFU} / \mathrm{L}$ in the salt mine and salt marshes, respectively. $\mathrm{pH}$ of the samples was neutral to slightly alkaline, ranging from 7.0 to 8.3. Measurements of EC of soil and mud samples showed values ranging from 5.4 to $13.9 \mathrm{dS} / \mathrm{m}$. EC of the aqueous samples from the sites 1,2 , and 3 showed values of $9.3 \mathrm{dS} / \mathrm{m}, 10.6 \mathrm{dS} / \mathrm{m}$, and $11.3 \mathrm{dS} / \mathrm{m}$, respectively, indicating the occurrence of high salt concentrations in such samples. However, EC of the water source (WSS1) feeding site 1 showed a low value of $2.1 \mathrm{dS} / \mathrm{m}$. Subsequently, samples were classified based on their EC values in salinity categories, distribution of soil samples studied according to the USSLS standards by Richards (1954), and water samples according to Rhoades et al. (1992) (see Table 1). The mineral profiling of the samples showed a high content of $\mathrm{Na}^{+}, \mathrm{Mg}^{2+}, \mathrm{Ca}^{2+}$, and $\mathrm{K}^{+}$. Soil and mud samples from the three sites showed the predominance of sodium and calcium ions, with concentrations ranging from $1.5 \mathrm{~g} / \mathrm{L}$ to more than $1000 \mathrm{~g} / \mathrm{L} . \mathrm{K}^{+}$ and $\mathrm{Mg}^{2+}$ ions follow at relatively lower concentration (see Table 2). Other ions such as $\mathrm{Ni}^{2+}$ and $\mathrm{Cd}^{2+}$ were present at concentrations less than $0.03 \mathrm{~g} / \mathrm{L}$ in the three sites. Yet, $\mathrm{Al}^{3+}, \mathrm{Co}^{2+}, \mathrm{Cr}^{2+}, \mathrm{Cu}^{2+}$, and $\mathrm{Fe}^{2+}$ ions showed concentrations less than $0.01 \mathrm{~g} / \mathrm{L}$. Analysis of the bacterial load from the solid samples (mud and soil) showed a positive correlation with the concentration of mineral ions, mainly sodium, magnesium, and calcium ions. However, bacterial loads from aqueous samples showed a negative correlation with ions concentrations (Fig. 1). Strong correlations were obtained between bacterial load/ halophilic bacteria frequency from solid samples (mud and soil) and salt concentrations of the quantified ionic entities. This situation was reversed in aqueous samples: the higher the salt concentration, the lower the bacterial load. Furthermore, depending on the isolation site, bacterial load responded differently to the different ions $(\mathrm{Na}, \mathrm{K}$, $\mathrm{Mg}, \mathrm{Mn}$, and $\mathrm{Ca}$ ) at different concentrations, with a preference to the presence of $\mathrm{Na}^{+}$ion. These differences in bacterial loads from solid to aqueous samples may be explained by water activity as well as the ionic strength (Fox-Powell et al. 2016) and the availability of the ionic forms of the corresponding salts in the biotope (more free ions in the aqueous samples than in the solid ones). Also, it is worth mentioning that, in contrast to what is commonly accepted regarding salinity, such correlations indicate an increase in the bacterial load-mainly the increase in the frequency of halophilic bacteria-with an increase of salt concentration in solid samples, as opposed to the aqueous samples. On the other hand, organic matter content showed a relatively high percentage-ranging from 8 to $12 \%(\mathrm{w} / \mathrm{w}$ or $\mathrm{w} / \mathrm{v})$-in both aqueous and solid samples, but the correlation with the bacterial load showed a low and a divergent response to organic matter. In solid samples, the water content showed a negative correlation with the microbial load. The $\mathrm{BOD}_{5}$ of the aqueous samples showed values ranging from 0.54 to $1.6\left(\mathrm{~g} \mathrm{O}_{2} / \mathrm{L}\right)$, and the values of total COD in the soil of sites 1 and 2 (SS1 and SS2) were higher compared to other samples (water and mud) in the same site. In contrast, site 3 showed high

Table 1 Physical and chemical properties of the samples from the three sites

\begin{tabular}{|c|c|c|c|c|c|c|c|c|c|c|c|}
\hline \multirow[b]{3}{*}{ Samples classification } & \multicolumn{5}{|l|}{ Site 1, JZ } & \multicolumn{3}{|l|}{ Site $2, \mathrm{M}$} & \multicolumn{3}{|c|}{ Site $3, \mathrm{BM}$} \\
\hline & $\overline{W S^{c}}$ & $W M^{d}$ & SS & $S^{d}$ & $M^{d}$ & $\overline{W^{c}}$ & $S^{d}$ & $M^{d}$ & $\overline{W^{c}}$ & $S^{d}$ & $M^{d}$ \\
\hline & $\begin{array}{l}\text { Moderately } \\
\text { saline }\end{array}$ & $\begin{array}{l}\text { Highly } \\
\text { saline }\end{array}$ & $\begin{array}{l}\text { Extremely } \\
\text { saline }\end{array}$ & Saline & $\begin{array}{l}\text { Slightly } \\
\text { saline }\end{array}$ & $\begin{array}{l}\text { Highly } \\
\text { saline }\end{array}$ & Saline & $\begin{array}{l}\text { Slightly } \\
\text { saline }\end{array}$ & $\begin{array}{l}\text { Highly } \\
\text { saline }\end{array}$ & Saline & $\begin{array}{l}\text { Slightly } \\
\text { saline }\end{array}$ \\
\hline$\overline{\mathrm{pH}^{\mathrm{a}}}$ & 7.0 & 7.0 & NA & 7.7 & 7.9 & 8.0 & 7.6 & 8.1 & 7.5 & 7.7 & 8.3 \\
\hline Conductivity $(\mathrm{dS} / \mathrm{m})^{\mathrm{b}}$ & 2.1 & 9.3 & 13.9 & 10.5 & 5.4 & 10.6 & 9.4 & 4.9 & 11.3 & 9.2 & 5.4 \\
\hline Salinity (\%) & 4.5 & 19.5 & 29.2 & 22.0 & 12.0 & 22.4 & 19.7 & 10.4 & 23.7 & 19.3 & 11.2 \\
\hline $\mathrm{CFU} / \mathrm{g}$ & ND & ND & $1.25 .10^{5}$ & $2.9 .10^{5}$ & $3.3 .10^{6}$ & ND & $2.85 .10^{6}$ & $2.85 .10^{6}$ & ND & $2.95 .10^{6}$ & $2.85 .10^{6}$ \\
\hline CFU/L & 1.5. $10^{6}$ & $2.2 .10^{5}$ & ND & ND & ND & $2.25 .10^{6}$ & ND & ND & $2.85 .10^{5}$ & ND & ND \\
\hline Number of halophilic & ND & 17 & 13 & 71 & 65 & 17 & 14 & 8 & 6 & 4 & 12 \\
\hline $\begin{array}{l}\text { Number of hydrolases- } \\
\text { producing bacteria }\end{array}$ & ND & 12 & 13 & 64 & 55 & 15 & 14 & 8 & 5 & 2 & 1 \\
\hline Total & 166 & & & & & 39 & & & 22 & & \\
\hline
\end{tabular}

WS water of the source, $W M$ water inside the mine, SS salt sediment, $W$ water of the site, $S$ soil, $M$ Mud, ND not determined

${ }^{\mathrm{a} M i n i m a l} /$ maximal for the season

'Conductivity and salinity were measured by "water quality instrument, YSI Scientific"

${ }^{c}$ The water is saline if EC $>0.25 \mathrm{dS} / \mathrm{m}$

${ }^{\mathrm{d}}$ The soil is saline if $\mathrm{EC}>4.0 \mathrm{dS} / \mathrm{m}$ 
Table 2 Mineral profile and classification of each studied site

\begin{tabular}{|c|c|c|c|c|c|c|c|c|c|c|c|}
\hline & Site 1, & & & & & Site $2, \mathrm{~N}$ & & & Site $3, \mathrm{E}$ & & \\
\hline & $\overline{W^{a}}$ & $W M^{a}$ & $\mathrm{SS}^{\mathrm{b}}$ & $\mathrm{S}^{\mathrm{b}}$ & $M^{b}$ & $\overline{W^{a}}$ & $\mathrm{~S}^{\mathrm{b}}$ & $M^{b}$ & $\overline{W^{a}}$ & $S^{b}$ & $M^{b}$ \\
\hline$C a^{a, b}$ & $<0.01$ & 60.62 & ND & 0.151 & 3.09 & 82.81 & 93.52 & $>1000$ & 21.33 & 725.25 & 218.29 \\
\hline$K^{a, b}$ & $<0.01$ & 7.00 & ND & 5.47 & 5.58 & 12.58 & 5.95 & 12.58 & 1.43 & 12.79 & 10.03 \\
\hline $\mathrm{Mg}^{\mathrm{a}, \mathrm{b}}$ & $<0.01$ & 18.32 & ND & $<0.01$ & $<0.01$ & 1.49 & 1.89 & 28.17 & 3.74 & 35.01 & 17.08 \\
\hline$M n^{a, b}$ & 0.035 & 0.18 & ND & 0.035 & 0.074 & 0.110 & 0.106 & 0.130 & 0.171 & 0.171 & 0.117 \\
\hline $\mathrm{Na}^{\mathrm{a}, \mathrm{b}}$ & 1.50 & 329.75 & ND & $>1000$ & $>1000$ & 340.29 & 881.23 & $>1000$ & 222.16 & 657.18 & 881.18 \\
\hline CDOt $\left(\mathrm{g} \mathrm{O}_{2} / \mathrm{l}\right)$ & 3.43 & 3.63 & ND & 8.88 & 0.90 & 2.42 & 7.57 & 0.90 & 24.24 & 1.79 & 1.28 \\
\hline $\mathrm{BOD}_{5}\left(\mathrm{~g} \mathrm{O}_{2} / \mathrm{l}\right)$ & 1.53 & 1.24 & ND & ND & ND & 1.60 & ND & ND & 0.54 & ND & ND \\
\hline Water content (\%) & ND & ND & ND & 12 & 41 & ND & 15 & 30 & ND & 10 & 35 \\
\hline Organic matter (\%) & 8 & 11.2 & ND & 6 & 8 & 6.06 & 7.05 & 10 & 12.5 & 10 & 11.5 \\
\hline Total dissolve salt (\%) & 5.4 & 22.9 & ND & 24.6 & 12.8 & 23.0 & 12.1 & 15.7 & 26.3 & 16.9 & 14.3 \\
\hline
\end{tabular}

WS water of the source, WM water of the mine, SS salt sediment, $W$ water of the site, $S$ soil, $M$ mud, ND not determined

alon concentration in $\mathrm{g} / \mathrm{L}$

blon concentration in $\mathrm{mg} / \mathrm{g}$

values of the total $\mathrm{COD}$ from the aqueous sample (WS3). $\mathrm{COD}_{\mathrm{t}} / \mathrm{BOD}_{5}$ ratio was $<2$ for sites 1 and 2 , indicating an easily biodegradable biotope. However, site 3 showed a ratio higher than 2, indicating a scarcely biodegradable biotope. When correlated, $\mathrm{BOD}_{5}$ and the microbial load from aqueous samples showed positive values, but no correlation was shown between the microbial load and the total COD or $\mathrm{BOD}_{5}$ from the solid samples.

\section{Phenotypic and phylogenetic diversity analysis of the isolated bacteria}

At first, a total of 227 pure strains were isolated based on their responses to different $\mathrm{NaCl}$ concentrations in the culture media. Moderate halophilic bacteria were the most represented category $(100 / 227)$ with predominance in site 2 (56.4\%), followed by site 1 (42.7\%) and then site 3 (31.8\%). Slight halophilic bacteria were more represented in site 3 (36.4\%), followed by site 1 (34.3\%) and site 2 (20.5\%). Halotolerant bacteria were represented in the collection by $35 /$
227 with a predominance in site $3(31.8 \%)$ followed by site $2(20.5 \%)$ and then site 1 (12.1\%). Nineteen of $227 \mathrm{ex}-$ tremely halophilic bacteria have been isolated in this collection. This category was more represented in site $1(10.8 \%)$ compared to site $2(2.6 \%)$, and no extremely halophilic bacterium was isolated from site 3 . Moreover, these frequencies appeared to be similar to the results obtained from marshes and salternes located in lower Loukkos in west of Morocco (8.6 \%), and we noticed the same pattern with regards to the genera described in this study in comparison to those by Berrada et al. (2012). Eighty strains out of 227 are Gram-negative (with 41/80 being rods and 39/80 cocci), and 147/227 were Gram-positive (with 112/147 being rods and 35/147 cocci). Particularly, 189/227 strains have shown promising extracellular hydrolytic production. The strains of this sub-collection of 189 strains were characterized and positioned at genus level based on their phenotypic characteristics as described by Bergey's Manual of Systematic Bacteriology (Boone et al. 2001; De Vos et al. 2012; Whitman et al. 2012; Krieg et al. 2012). Figures 2a and 3a show the

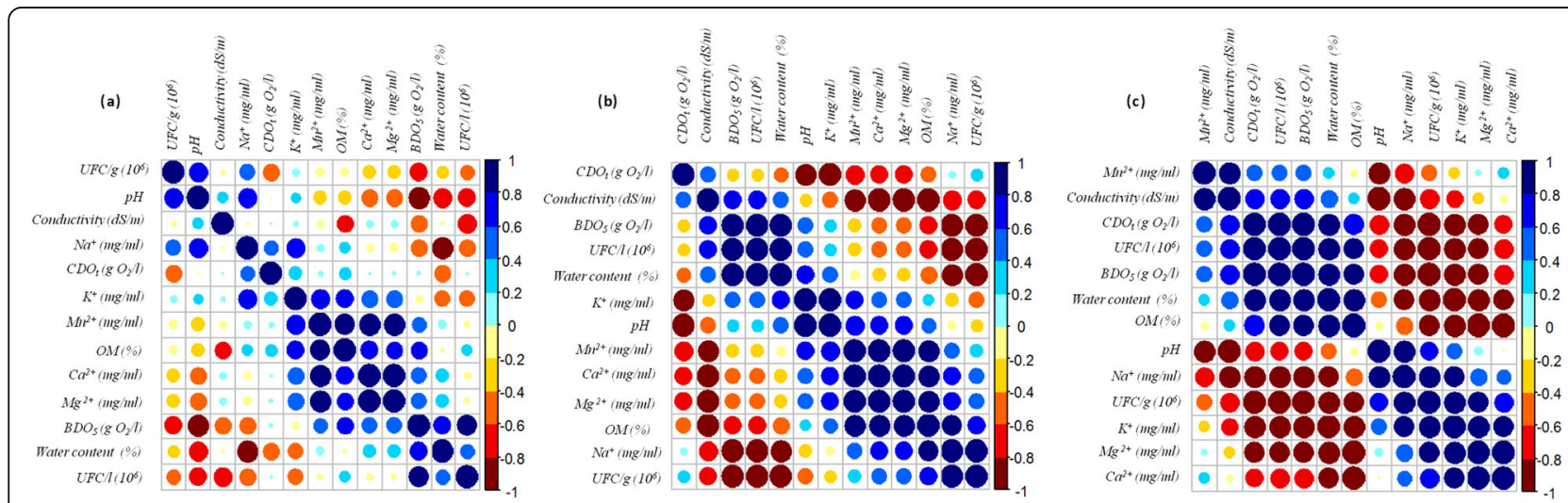

Fig. 1 Correlation matrix between the physicochemical properties and the bacterial load in the solid and aqueous samples in a site 1, b site 2, and $\mathbf{c}$ site 3 
(a)

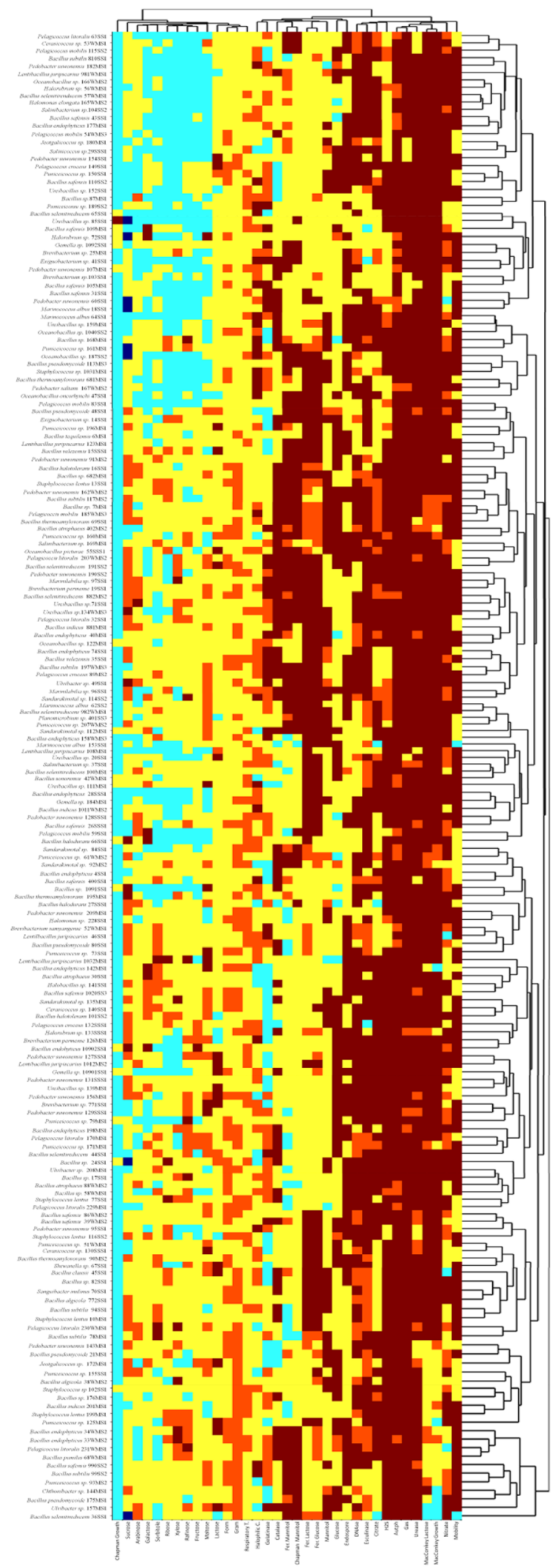

(b)

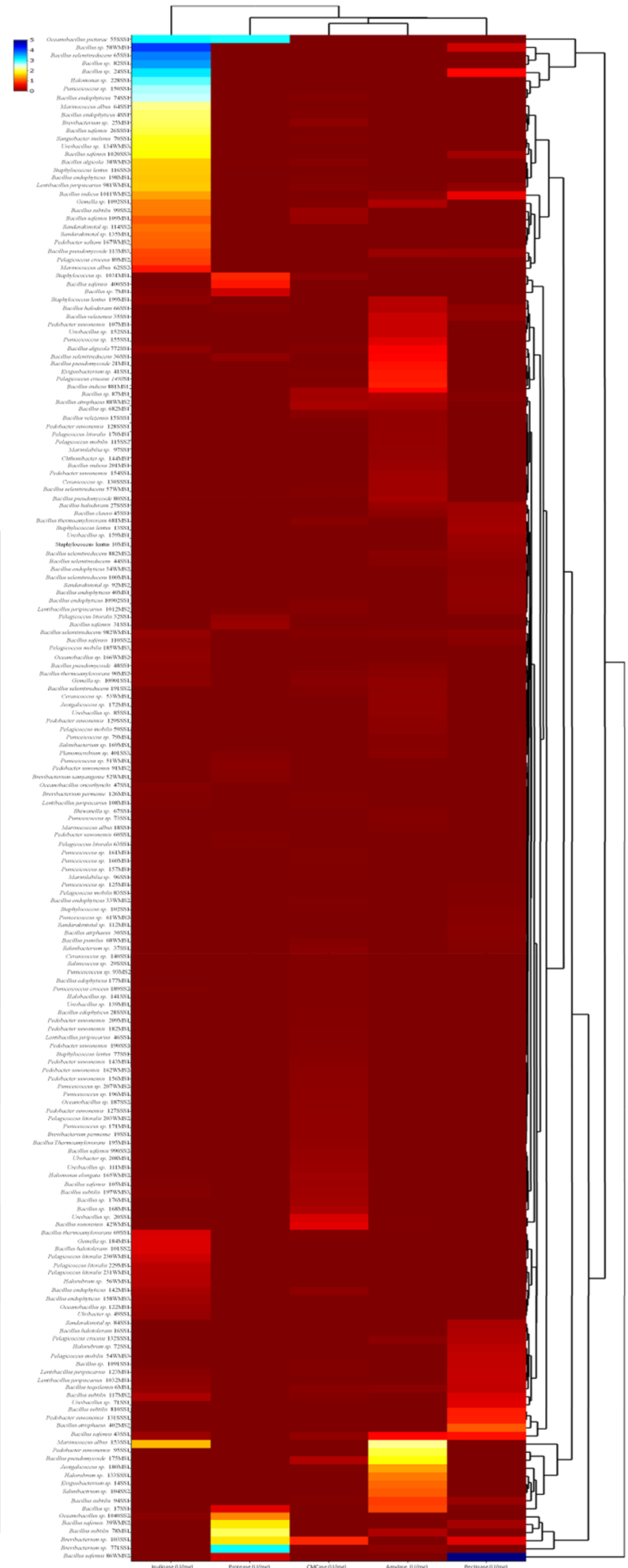


(See figure on previous page.)

Fig. 2 Clustering of the 189 isolates based on their phenotypic characteristics (a) and based on their enzymatic activities values (b). Values in the scales for (a) indicate the magnitude of the response to the assay in a scale from 0 to 5 , and values in the scales for (b) indicate the calculated enzymatic activities expressed in a scale from 0 to $100 \mathrm{U} / \mathrm{mg}$

clustering of the 189 halophilic strains with hydrolytic activities, based on their phenotypic properties, and the clustering of the sub-collection of 56 strains, with high hydrolytic activities, respectively. The data analysis shows that the distribution is relatively redundant at the genus level along the three sites. $B a$ cillus spp. were the most representative species in all three sites, in addition to Chthonibacter spp., Mariniabilia spp., Halobacillus spp., Salinococcus spp., Cerasicoccus spp., Ulvibacter spp., Halorubrum spp., Jeatgalicoccus spp., Brevibacterium spp., Sanguibacter spp., Shewanella spp., Exiguobacterium spp., and Gemella spp., which were obtained only from site 1. Planomicrobium spp. were present in site 3 only (Table 3). The analysis of the results displayed in Figs. 2 and 3 shows the predominance of bacteria belonging to the genera Pedobacter, Pelagicoccus, and Puniceicoccus as the representatives of the Gram-negative group. Gram-positive strains were dominated by the genera Bacillus, Staphylococcus, and Lentibacillus.

\section{Phylogenetic analysis}

Preliminary comparative phylogenetic relatedness of the selected halophilic bacteria with high hydrolytic enzyme production was carried out based on the $16 \mathrm{~S}$ rDNA gene. $16 \mathrm{~S}$ rDNA sequences corresponding to the size of $1420 \mathrm{bp}$ from the studied strains, as well as from type strains (Table 4 and Table S1), were analyzed for their phylogenetic relatedness. As far as the sampling site is concerned, the data obtained from the phylogenetic analysis led us to classify the isolates in nine genera: Bacillus, $44.6 \%$ from site 1, $16.1 \%$ from site 2, and 3.6\% from site 3; Staphylococcus, 14.3\%; Brevibacterium, 5.35\%; Shewanella, 1.8\%; Oceanobacillus, 5.35\%; Planomicrobium, 1.8\%; Exiguobacterium, 3.6\%; Sanguibacter, 1.8\%; and Halomonas, $1.8 \%$. We also found differences in the genera and species isolated (Fig. 2 and Fig. 3). For example, species of the genera Brevibacterium, Exiguobacterium, Oceanobacillus, Sanguibacter, and Shewanella were only found in site 1 . The genus Halomonas was only found only in site 2, and Planomicrobium was only

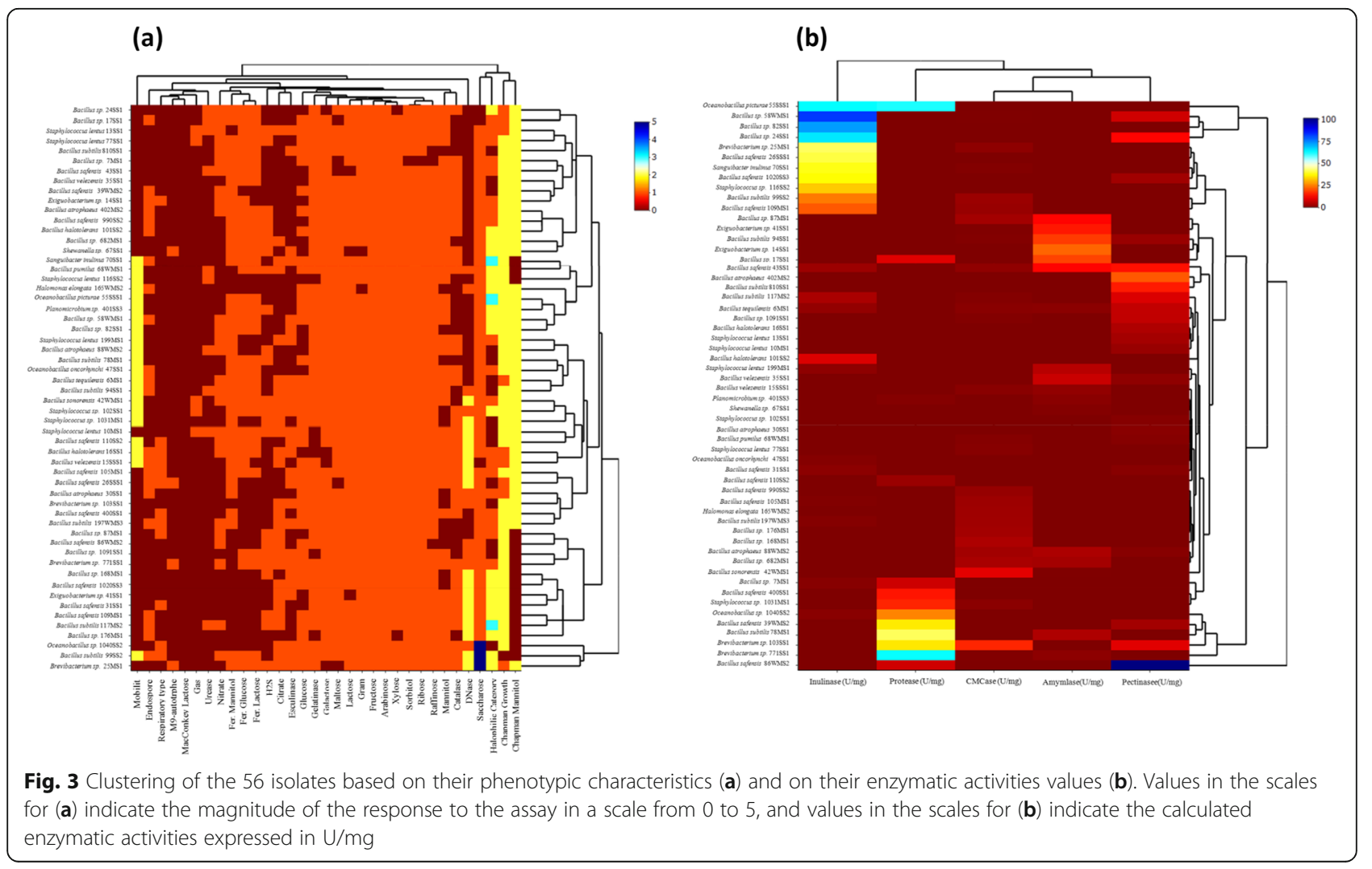


Table 3 Distribution of the different species showing hydrolytic activities according to their isolation site

\begin{tabular}{|c|c|c|c|c|}
\hline \multirow[t]{2}{*}{ Genus/species } & \multirow{2}{*}{$\begin{array}{l}\text { Total } \\
\text { number }\end{array}$} & \multicolumn{3}{|c|}{ Number per site } \\
\hline & & Site 1 & Site 2 & Site 3 \\
\hline Bacillus spp. & 72 & 52 & 16 & 4 \\
\hline Pedobacter spp. & 17 & 12 & 5 & 0 \\
\hline Pelagicoccus spp. & 15 & 10 & 3 & 2 \\
\hline Puniceicoccus spp. & 13 & 10 & 3 & 0 \\
\hline Ureibacillus spp. & 8 & 7 & 0 & 1 \\
\hline Staphylococcus spp. & 8 & 7 & 1 & 0 \\
\hline Lentibacillus spp. & 6 & 5 & 1 & 0 \\
\hline Brevibacterium spp. & 6 & 6 & 0 & 0 \\
\hline Oceanobacillus spp. & 6 & 3 & 3 & 0 \\
\hline Sandarakinotalea spp. & 5 & 3 & 2 & 0 \\
\hline Marinicoccus spp. & 4 & 3 & 1 & 0 \\
\hline Gemella spp. & 3 & 3 & 0 & 0 \\
\hline Salinibacterium spp. & 3 & 2 & 1 & 0 \\
\hline Halorubrum spp. & 3 & 3 & 0 & 0 \\
\hline Cerasicoccus spp. & 3 & 3 & 0 & 0 \\
\hline Ulvibacter spp. & 3 & 3 & 0 & 0 \\
\hline Halomonas spp. & 2 & 1 & 1 & 0 \\
\hline Jeatgalicoccus spp. & 2 & 2 & 0 & 0 \\
\hline Marinilabilia spp. & 2 & 2 & 0 & 0 \\
\hline Exiguobacterium spp. & 2 & 2 & 0 & 0 \\
\hline Salinicoccus spp. & 1 & 1 & 0 & 0 \\
\hline Planomicrobium spp. & 1 & 0 & 0 & 1 \\
\hline Chthonibacter spp. & 1 & 1 & 0 & 0 \\
\hline Halobacillus spp. & 1 & 1 & 0 & 0 \\
\hline Sanguibacter spp. & 1 & 1 & 0 & 0 \\
\hline Shewanella spp. & 1 & 1 & 0 & 0 \\
\hline Total & 189 & 144 & 37 & 8 \\
\hline
\end{tabular}

found in site 3. Nevertheless, genus Staphylococcus was isolated from sites 1 and 2. We applied the neighbor-joining criteria and obtained a phylogenetic tree, grouping the 56 sequences in eight groups (A$\mathrm{H})$ (Fig. 4). In the case of the phylogenetic tree constructed with the species of Bacillus (Fig. 5), we found 12 subgroups (A1-A12). The $16 \mathrm{~S}$ rDNA gene sequences from Bacillus sp. strains strain 7MS1 (MK713705), Bacillus sp. strain 682MS1 (MK713707), and Bacillus sp. strain 176MS1 (MK713714), showed a relationship of less than $98 \%$ with other related type strains. Regarding the genus Bacillus, strains with closely similar $16 \mathrm{~S}$ rDNA sequences displayed different biochemical characteristics, which is worth considering for future studies in order to resolve whether they constitute new species or subspecies within their related genera.
Group A, represented by strains of the genus $\mathrm{Ba}$ cillus, was the dominant group (36) among the isolated strains. Figure 5 shows the neighbor-joining sub-tree of this group. Bacillus safensis was the major representative (27.77\%) within this group, followed by Bacillus subtilis (16.66\%), Bacillus atrophaeus (8.33\%), and Bacillus halotolerans (5.33\%). Species of Bacillus velezensis represented $5.55 \%$ and Bacillus tequilensis have been isolated from site 1 only. Group B was denoted by strains from the genus Staphylococcus, as the second dominant genus from the studied sites, represented mainly by Staphylococcus lentus but with a remarkable diversity in their biochemical characteristics, more specifically their hydrolase activities (Fig. 2 and Fig. 3). So far, species of the genus Staphylococcus have never been described as halophilic bacteria, but rather as haloduric ones. Ten strains of Staphylococcus were largely halotolerant, tolerating $\mathrm{NaCl}$ concentrations from 0 to $300 \mathrm{~g} / \mathrm{L}$. Moreover, they showed themselves to be poly-halophilic, by being halotolerant, and also extremely halophilic, tolerating high salt concentrations ranging from 150 to $300 \mathrm{~g} / \mathrm{L}$ of $\mathrm{NaCl}$ (Table 4). Group C is represented by three strains identified as genus Oceanobacillus. Strains Oceanobacillus oncorhynchi 47SS1 and Oceanobacillus picturae 55SSS1 were isolated from site 1 (salt mine) and showed different tolerance windows to salt concentrations, with a range of $10-210 \mathrm{~g} / \mathrm{L}$ and 150 $210 \mathrm{~g} / \mathrm{L}$, respectively. Oceanobacillus sp. 1040SS2, isolated from site 2, was characterized as a halotolerant bacterium with extended range of salt tolerance from 0 to $270 \mathrm{~g} / \mathrm{L}$.

One species, identified as a Planomicrobium sp. strain 401SS3 and isolated from site 3 (salt marsh), is the only representative of the group D. Strain 401SS3 showed a halophilic behavior with an optimal range of growth from 30-210 g/L. Genus Planomicrobium has been reported in specimens from marine environments (seafood, coastal sediments, Antarctic sea ice), with a tolerance range from 0 to $140 \mathrm{~g} / \mathrm{L}$ (Yoon et al. 2015). Group E is represented by two species of the genus Exiguobacterium. This genus has been widely described as a diverse group found in different habitats, but less described in saline environments (Oren 2015; Ventosa et al. 2015; Remonsellez et al. 2018). Phylogenetic phenotypic analysis of Exiguobacterium sp. strain 14SS1 (MK713684) and Exiguobacterium sp. strain 41SS1 (MK713691) showed a relatively higher salt tolerance $(10-180 \mathrm{~g} / \mathrm{L}$ and $30-180 \mathrm{~g} / \mathrm{L}$, respectively), compared to reported strains from the same phylotype (Remonsellez et al. 2018). Brevibacteria have been isolated from several habitats, particularly from high salt concentration environments such as 
Table 4 Accession numbers of the strains of the collection as well as their range of $\mathrm{NaCl}$ concentration for optimal growth and their enzymatic activities expressed in $\mathrm{U} / \mathrm{mg}$

\begin{tabular}{|c|c|c|c|c|c|c|c|}
\hline Strain name & $\begin{array}{l}\text { 16S rDNA accession } \\
\text { numbers }\end{array}$ & $\begin{array}{l}\mathrm{NaCl} \text { range tolerance } \\
\text { for growth }(\mathrm{g} / \mathrm{L})\end{array}$ & $\begin{array}{l}\text { Cellulase } \\
(\mathrm{U} / \mathrm{mg})\end{array}$ & $\begin{array}{l}\text { Amylase } \\
(\mathrm{U} / \mathrm{mg})\end{array}$ & $\begin{array}{l}\text { Protease } \\
(\mathrm{U} / \mathrm{mg})\end{array}$ & $\begin{array}{l}\text { Pectinase } \\
(\mathrm{U} / \mathrm{mg})\end{array}$ & $\begin{array}{l}\text { Inulinase } \\
(\mathrm{U} / \mathrm{mg})\end{array}$ \\
\hline Bacillus atrophaeus 30551 & MK713688 & $10-60$ & 0.00 & 0.00 & 0.00 & $0.97 \pm 0.06$ & 0.00 \\
\hline Bacillus atrophaeus 402552 & MK713721 & $10-60$ & 0.00 & 0.00 & 0.00 & $21.40 \pm 3.02$ & 0.00 \\
\hline Bacillus atrophaeus 88WMS2 & MK713729 & $0-60$ & $3.46 \pm 0.17$ & $1.73 \pm 0.14$ & 0.00 & $0.39 \pm 0.04$ & 0.00 \\
\hline Bacillus halotolerans $16 \mathrm{SS} 1$ & MK713685 & $10-90$ & 0.00 & 0.00 & 0.00 & $4.63 \pm 0.13$ & 0.00 \\
\hline Bacillus halotolerans 101552 & MK713724 & $30-120$ & 0.00 & 0.00 & 0.00 & 0.00 & $9.13 \pm 1.46$ \\
\hline Bacillus pumilus 68WMS1 & MK713720 & $30-120$ & $1.02 \pm 0.20$ & 0.00 & 0.00 & $0.39 \pm 0.07$ & 0.00 \\
\hline Bacillus safensis 105MS1 & MK713711 & $10-60$ & $2.96 \pm 1.03$ & 0.00 & 0.00 & 0.00 & $0.27 \pm 0.12$ \\
\hline Bacillus safensis 31551 & MK713689 & $60-120$ & 0.00 & 0.00 & $0.03 \pm 0.01$ & 0.00 & 0.00 \\
\hline Bacillus safensis $4005 S 1$ & ND & $10-120$ & 0.00 & 0.00 & $1.89 \pm 0.25$ & 0.00 & 0.00 \\
\hline Bacillus safensis 39 WMS2 & ND & $0-120$ & 0.00 & 0.00 & $0.83 \pm 0.10$ & $3.54 \pm 0.34$ & 0.00 \\
\hline Bacillus safensis 26SSS1 & MK713716 & $0-180$ & 0.00 & 0.00 & 0.00 & 0.00 & $41.28 \pm 1.81$ \\
\hline Bacillus safensis $1105 s 2$ & MK713725 & $0-210$ & 0.00 & 0.00 & 0.00 & $0.88 \pm 0.27$ & $1.40 \pm 0.22$ \\
\hline Bacillus safensis 86WMS2 & MK713728 & $0-60$ & 0.00 & 0.00 & $0.03 \pm 0.01$ & $11.12 \pm 0.49$ & 0.00 \\
\hline Bacillus safensis $9905 s 2$ & MK713723 & $10-60$ & $2.26 \pm 0.84$ & 0.00 & 0.00 & 0.00 & 0.00 \\
\hline Bacillus safensis 1020553 & MK713731 & $30-120$ & 0.00 & 0.00 & 0.00 & $3.40 \pm 0.41$ & $37.96 \pm 6.97$ \\
\hline Bacillus safensis 109MS1 & MK713712 & $30-180$ & $2.49 \pm 0.18$ & 0.00 & 0.00 & 0.00 & $21.44 \pm 1.80$ \\
\hline Bacillus sp. 24551 & MK713687 & $30-210$ & $0.09 \pm 0.01$ & 0.00 & 0.00 & $12.95 \pm 0.06$ & $65.37 \pm 4.60$ \\
\hline Bacillus sp. 17Ss1 & MK713686 & $10-60$ & 0.00 & $3.23 \pm 0.63$ & $1.06 \pm 0.13$ & 0.00 & 0.00 \\
\hline Bacillus sp. 43551 & MK713692 & $10-180$ & $1.72 \pm 0.54$ & $12.98 \pm 2.12$ & 0.00 & $14.18 \pm 2.30$ & $2.86 \pm 0.01$ \\
\hline Bacillus sp. $825 s 1$ & MK713699 & $30-150$ & 0.00 & 0.00 & 0.00 & 0.00 & $72.89 \pm 2.46$ \\
\hline Bacillus sp. 682MS1 & MK713707 & $30-120$ & $0.90 \pm 0.06$ & $3.70 \pm 1.23$ & 0.00 & 0.00 & 0.00 \\
\hline Bacillus sp. 168MS1 & MK713713 & $30-150$ & $1.64 \pm 0.21$ & 0.00 & 0.00 & 0.00 & 0.00 \\
\hline Bacillus sp. 87MS1 & MK713709 & $10-90$ & $3.55 \pm 1.45$ & $12.98 \pm 0.08$ & 0.00 & 0.00 & 0.00 \\
\hline Bacillus sp. 7MS1 & MK713705 & $10-150$ & 0.00 & 0.00 & $0.46 \pm 0.19$ & 0.00 & $0.78 \pm 0.01$ \\
\hline Bacillus sp. 176MS1 & MK713714 & $30-150$ & $1.25 \pm 0.06$ & 0.00 & 0.00 & 0.00 & 0.00 \\
\hline Bacillus sp. 42WMS1 & MK713718 & $10-120$ & $10.02 \pm 2.24$ & $0.03 \pm 0.01$ & 0.00 & 0.00 & 0.00 \\
\hline Bacillus sp. 58WMS1 & MK713719 & $30-120$ & $0.07 \pm 0.05$ & 0.00 & 0.00 & $7.93 \pm 1.34$ & $66.51 \pm 0.87$ \\
\hline Bacillus subtilis $94 \mathrm{SS} 1$ & MK713700 & $0-120$ & $0.01 \pm 0.00$ & $0.90 \pm 0.03$ & 0.00 & $0.21 \pm 0.07$ & 0.00 \\
\hline Bacillus subtilis 78MS1 & MK713708 & $0-120$ & 0.00 & $0.77 \pm 0.15$ & $0.03 \pm 0.15$ & 0.00 & 0.00 \\
\hline Bacillus subtilis 99552 & MK713722 & $60-200$ & $2.75 \pm 0.87$ & 0.00 & 0.00 & 0.00 & $24.78 \pm 7.05$ \\
\hline Bacillus subtilis 810551 & MK713698 & $0-120$ & 0.00 & 0.00 & 0.00 & $7.16 \pm 0.63$ & 0.00 \\
\hline Bacillus subtilis 117MS2 & MK713727 & $150-210$ & $0.54 \pm 0.15$ & 0.00 & 0.00 & $9.13 \pm 0.62$ & $4.26 \pm 1.01$ \\
\hline Bacillus subtilis 197WMS3 & MK713732 & $10-90$ & $3.27 \pm 0.62$ & 0.00 & 0.00 & 0.00 & $0.27 \pm 0.16$ \\
\hline Bacillus tequilensis 6MS1 & MK713704 & $0-270$ & $0.96 \pm 0.18$ & $1.18 \pm 0.66$ & 0.00 & $6.69 \pm 0.93$ & $2.01 \pm 0.11$ \\
\hline Bacillus velezensis $35 \mathrm{SS} 1$ & MK713690 & $0-90$ & 0.00 & $2.91 \pm 0.41$ & 0.00 & $1.55 \pm 0.09$ & 0.00 \\
\hline Bacillus velezensis $15 \mathrm{SSS} 1$ & ND & $10-90$ & $1.03 \pm 0.17$ & $1.84 \pm 0.10$ & 0.00 & 0.00 & 0.00 \\
\hline Brevibacterium sp. $1035 \mathrm{~s} 1$ & MK713702 & $0-120$ & $16.33 \pm 4.77$ & 0.00 & $0.28 \pm 0.05$ & $9.71 \pm 2.91$ & 0.00 \\
\hline Brevibacterium sp. $7715 s 1$ & MK713697 & $10-90$ & $0.31 \pm 0.14$ & $1.39 \pm 0.29$ & $0.35 \pm 0.06$ & 0.00 & 0.00 \\
\hline Brevibacterium sp. $25 \mathrm{MS} 1$ & ND & $30-210$ & $0.09 \pm 0.00$ & 0.00 & 0.00 & 0.00 & $0.07 \pm 0.11$ \\
\hline Exiguobacterium sp. $14 \mathrm{SS} 1$ & MK713684 & $10-180$ & 0.00 & $0.09 \pm 0.02$ & 0.00 & 0.00 & 0.00 \\
\hline Exiguobacterium sp. $41 \mathrm{sS} 1$ & MK713691 & $30-180$ & $0.16 \pm 0.05$ & $14.93 \pm 2.57$ & 0.00 & 0.00 & 0.00 \\
\hline Halomonas elongata 165WMS2 & ND & $60-270$ & $3.16 \pm 0.34$ & 0.00 & 0.00 & 0.00 & 0.00 \\
\hline Oceanobacillus oncorhynchi 47SS1 & MK713693 & $10-210$ & 0.00 & 0.00 & 0.00 & 0.00 & $0.44 \pm 0.10$ \\
\hline
\end{tabular}


Table 4 Accession numbers of the strains of the collection as well as their range of $\mathrm{NaCl}$ concentration for optimal growth and their enzymatic activities expressed in $\mathrm{U} / \mathrm{mg}$ (Continued)

\begin{tabular}{|c|c|c|c|c|c|c|c|}
\hline Strain name & $\begin{array}{l}16 \mathrm{~S} \text { rDNA accession } \\
\text { numbers }\end{array}$ & $\begin{array}{l}\mathrm{NaCl} \text { range tolerance } \\
\text { for growth }(\mathrm{g} / \mathrm{L})\end{array}$ & $\begin{array}{l}\text { Cellulase } \\
(\mathrm{U} / \mathrm{mg})\end{array}$ & $\begin{array}{l}\text { Amylase } \\
(\mathrm{U} / \mathrm{mg})\end{array}$ & $\begin{array}{l}\text { Protease } \\
(\mathrm{U} / \mathrm{mg})\end{array}$ & $\begin{array}{l}\text { Pectinase } \\
(\mathrm{U} / \mathrm{mg})\end{array}$ & $\begin{array}{l}\text { Inulinase } \\
(\mathrm{U} / \mathrm{mg})\end{array}$ \\
\hline Oceanobacillus picturae $55 \mathrm{SSS} 1$ & MK713717 & $150-210$ & 0.00 & 0.00 & $1.64 \pm 0.18$ & 0.00 & $31.13 \pm 3.32$ \\
\hline Oceanobacillus sp. $1040 s 52$ & ND & $0-270$ & 0.00 & 0.00 & $0.49 \pm 0.11$ & 0.00 & $0.49 \pm 0.11$ \\
\hline Planomicrobium sp. 401553 & MK713730 & $30-210$ & 0.00 & $0.09 \pm 0.03$ & $0.01 \pm 0.00$ & 0.00 & 0.00 \\
\hline Sanguibacter inulinus 70551 & MK713695 & $150-210$ & $0.35 \pm 0.23$ & 0.00 & 0.00 & 0.00 & $25.74 \pm 0.44$ \\
\hline Shewanella sp. $675 s 1$ & MK713694 & $30-210$ & 0.00 & $0.01 \pm 0.00$ & 0.00 & 0.00 & 0.00 \\
\hline Staphylococcus lentus13SS1 & MK713683 & $10-210$ & 0.00 & 0.00 & 0.00 & $3.62 \pm 0.12$ & 0.00 \\
\hline Staphylococcus lentus77SS1 & MK713696 & $10-150$ & $0.05 \pm 0.02$ & 0.00 & 0.00 & 0.00 & 0.00 \\
\hline Staphylococcus lentus10MS1 & MK713706 & $0-300$ & 0.00 & 0.00 & 0.00 & $2.51 \pm 0.24$ & 0.00 \\
\hline Staphylococcus lentus199MS1 & MK713715 & $10-150$ & 0.00 & $5.56 \pm 1.08$ & 0.00 & 0.00 & $1.46 \pm 0.06$ \\
\hline Staphylococcus lentus $1165 S 2$ & MK713726 & $30-150$ & 0.00 & 0.00 & 0.00 & 0.00 & $0.36 \pm 0.14$ \\
\hline Staphylococcus sp. $1025 s 1$ & MK713701 & $30-150$ & 0.00 & 0.00 & 0.00 & $0.71 \pm 0.05$ & 0.00 \\
\hline Staphylococcus sp. 1031MS1 & MK713710 & $0-150$ & $1.18 \pm 0.04$ & 0.00 & $0.16 \pm 0.01$ & 0.00 & 0.00 \\
\hline Staphylococcus sp. 1091 Ss1 & ND & $0-180$ & $0.44 \pm 0.12$ & 0.00 & 0.00 & $6.50 \pm 1.39$ & 0.00 \\
\hline
\end{tabular}

ND not determined

sea water (Lee 2008) and sediment samples (Küster and Williams 1964). The genus Brevibacterium (group F) is represented by three species denoted Brevibacterium sp. strain 103SS1, Brevibacterium sp. strain 771SS1, and Brevibacterium sp. strain 25MS1 and were found in Mount Zalagh only. $\mathrm{NaCl}$ tolerance of these strains ranges $0-120 \mathrm{~g} / \mathrm{L}, 10-90 \mathrm{~g} / \mathrm{L}$, and $30-$ $210 \mathrm{~g} / \mathrm{L}$, respectively, as compared to reports on strains from the same genus ranging from 50 to 180 g/L (Trujillo and Goodfellow 2015). Sanguibacter inulinus strain 70SS1 as a sole representative of the group $G$ shows a slightly high salt tolerance ranging from 150 to $210 \mathrm{~g} / \mathrm{L}$. Data on halophilic bacteria from this genus remains scarce, with some species of this genus being described as slightly halotolerant, within the range of 0 to $70 \mathrm{~g} / \mathrm{L}$ of $\mathrm{NaCl}$ (Ramos et al. 2015). Group $\mathrm{H}$ was represented by Shewanella sp. strain $67 \mathrm{SS1}$, isolated from site 1 . It shows a broad range of $\mathrm{NaCl}$ tolerance from $30-210 \mathrm{~g} / \mathrm{L}$, in contrast to most species of this genus described as slightly halotolerant with average $\mathrm{NaCl}$ tolerance range from 0 to $60 \mathrm{~g} / \mathrm{L}$ (Bowman 2015). Generally, species of Shewanella have been described to be strictly of marine origin, and several species of this genus Shewanella have been isolated from various saline habitats, including salt marshes (Rosselló-Mora et al. 1995), from marine algae (Simidu et al. 1990), seawater, and salted food products (Vogel et al. 1997). Phylogenetic and phenotypic data clustering showed divergent results, thus indicating remarkable diversity within the isolated strains in this work, in line with what has been discussed by other reports (Berrada et al. 2012).

\section{Hydrolytic activities of halophilic bacteria}

The qualitative test on agar plates allowed the determination of the 189 strains (out of the 227 of the collection) demonstrating at least one of the fives tested activities. As shown if Fig. 6, the isolated bacteria showed differences in the production and release of hydrolytic enzymes as function of $\mathrm{NaCl}$ concentrations. Actually, conventional assay for pectinases production in agar media using copper acetates failed to reveal the clear zone at high $\mathrm{NaCl}$ concentrations in the medium. Instead, layering the agar plate with iodine reagent has succeeded to reveal the clear zone that indicates the breakdown of PGA to their reducing sugars (Fig. $6 \mathrm{~d}, \mathrm{~d}^{\prime}$ ). The results of the production and activity in submerged cultures confirmed the activities in the conditions tested. Figure $2 \mathrm{~b}$ and Fig. $3 \mathrm{~b}$ show the clustering of the 56 halophilic bacteria (collection with $16 \mathrm{~S}$ rDNA sequenced) and of the 189 halophilic strains, respectively, based on quantitative assays for hydrolytic enzyme production in submerged cultures. All the strains were able to produce hydrolytic enzymes within their range of $\mathrm{NaCl}$ tolerance. Out of the 189 strains with hydrolytic activity, 42.85\% were cellulase producers, $33.86 \%$ were amylase positive, $33.33 \%$ were inulinase positive, $38.04 \%$ were pectinase positive, and $12.16 \%$ were proteases positive. 93.75\% of the Gram-negative strains showed hydrolytic activities as opposed to $77.55 \%$ for the Grampositive ones.

Table 4 shows the enzymatic activities (as $\mathrm{U} / \mathrm{mg}$ of total proteins from the cell free medium) of the 56 isolates. The strains showed the capacity to produce, in 


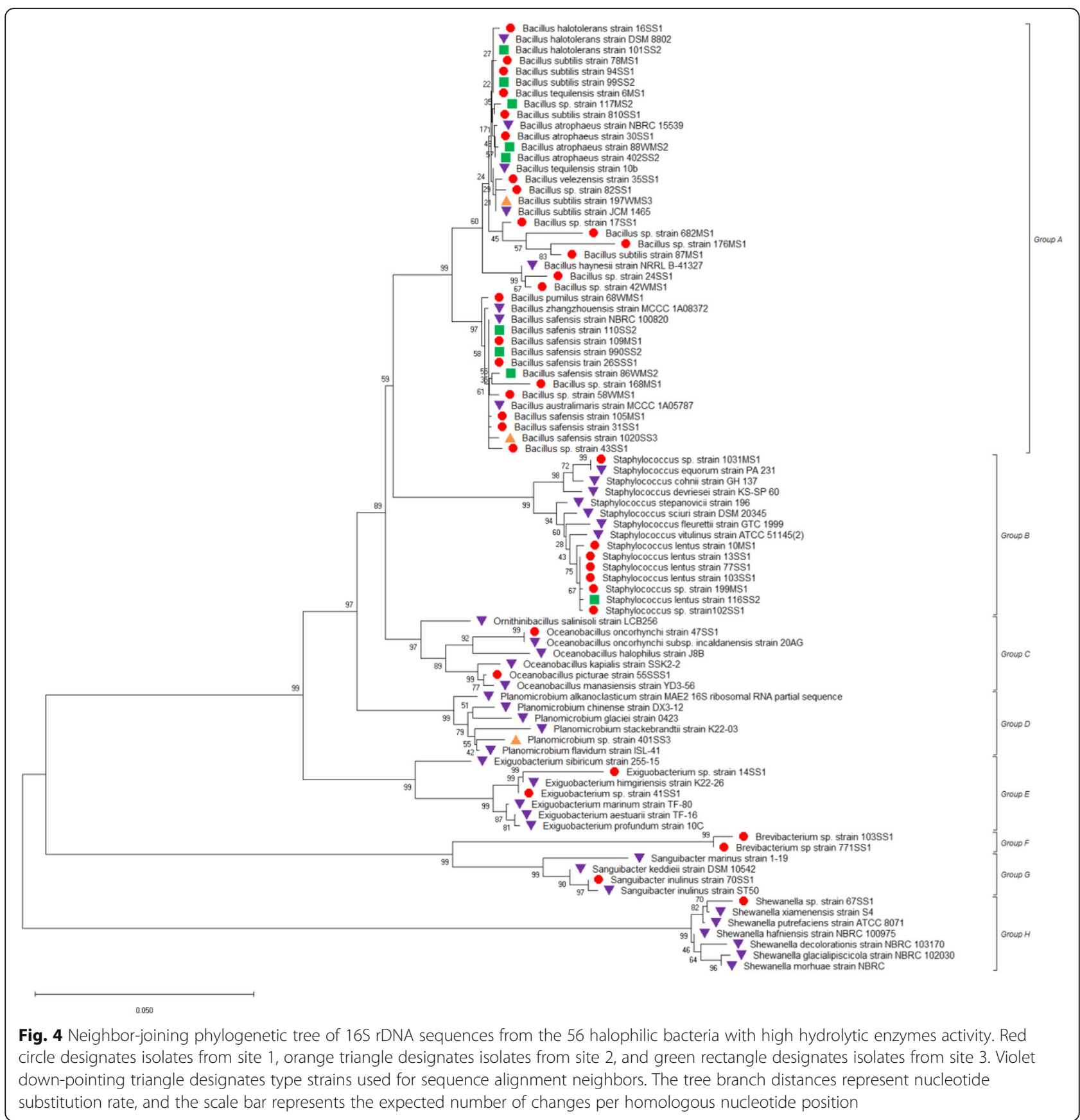

some cases, more than one activity, which can be a way of adaptation to such harsh conditions. Some bacteria develop diverse ability to cope with the low nutriment availability, like motility to acquire nutriments rapidly or the ability to use different carbon and energy sources (Vera-Gargallo and Ventosa 2018). The moderately and the slightly halophilic bacteria showed remarkable hydrolytic activities compared to the extremely halophilic strains. The genera Bacillus, Pedobacter, Pelagicoccus, Puniceicoccus, Salinibacterium, and Brevibacterium isolates presented more than one hydrolytic activity pattern. Inulinase, cellulase, pectinase, amylase, and protease activities were expressed by numerous strains belonging to $18,17,16,16$, and 10 different genera respectively (Table 4 and Figs. $2 \mathrm{~b}$ and $3 \mathrm{~b}$ ).

As shown in Table 4, data related to the enzymatic performances of the isolated species in this study from different samples exhibited differences in their enzymatic behaviors as well as their tolerance to salt concentration (Ortega et al. 2011). Such data could be linked to the 


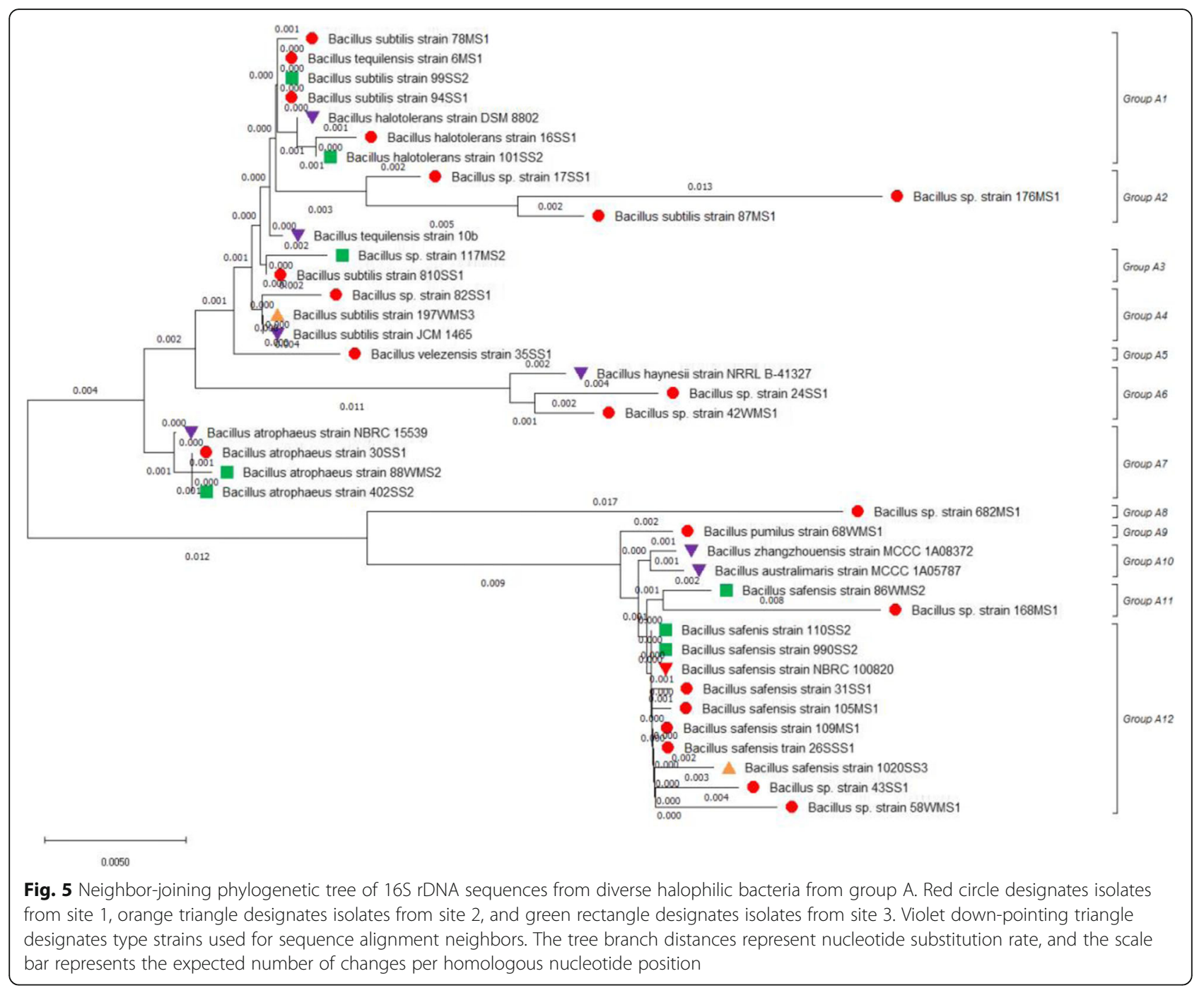

effect of the environment on the rearrangement of genetic information to induce/improve the performances of hydrolytic enzymes needed for the breakdown of complex polymeric substrates (He et al. 2010). The qualitative enzymatic assays showed that the categories of slightly halophilic and halotolerant bacteria were highly represented among hydrolytic halophilic bacteria (47.4\%, $39.6 \%$, and $41 ; 2 \%$ for CMCase activity; $38.15 \%, 33.3 \%$, and $23.5 \%$ for amylase activity; $35.5 \%, 22.9 \%$, and $23.5 \%$ for pectinase activity; and $13.15 \%, 12.5 \%$, and $5.9 \%$ for protease activity, respectively). Extremely halophilic bacteria showed the highest percentage for the inulinase activity, with $52.9 \%$ versus $26.04 \%$ for the moderate halophilic and $38.15 \%$ for the slightly halophilic and halotolerant. This result could suggest an adaptation of such halophilic bacteria to harsh environments where hardly degradable substrates such as inulin are most dominants rather than easily metabolized substrates. Furthermore, we noticed an increase in the number of isolates having extracellular enzymatic activities in high $\mathrm{NaCl}$ concentration (see Table 3). When assayed in liquid culture media, all isolates reproduced the same activities as agar media, nevertheless, is not quite sufficient to compare between the strains, but it gives qualitative insights toward the expressed enzymatic activity. The difference in activity seen within the same genera, and sometimes species, can be explained by the inoculation that was made by a colony. Halotolerant and slightly halotolerant isolates showed the highest enzymatic activities compared to the moderately and extremely halophilic bacteria. Actually, the main enzymatic activities for the slightly halophilic and halotolerant groups were for cellulase and amylase assays. In contrast, most of the moderately halophilic strains showed moderate cellulase enzyme production and high inulinase, 


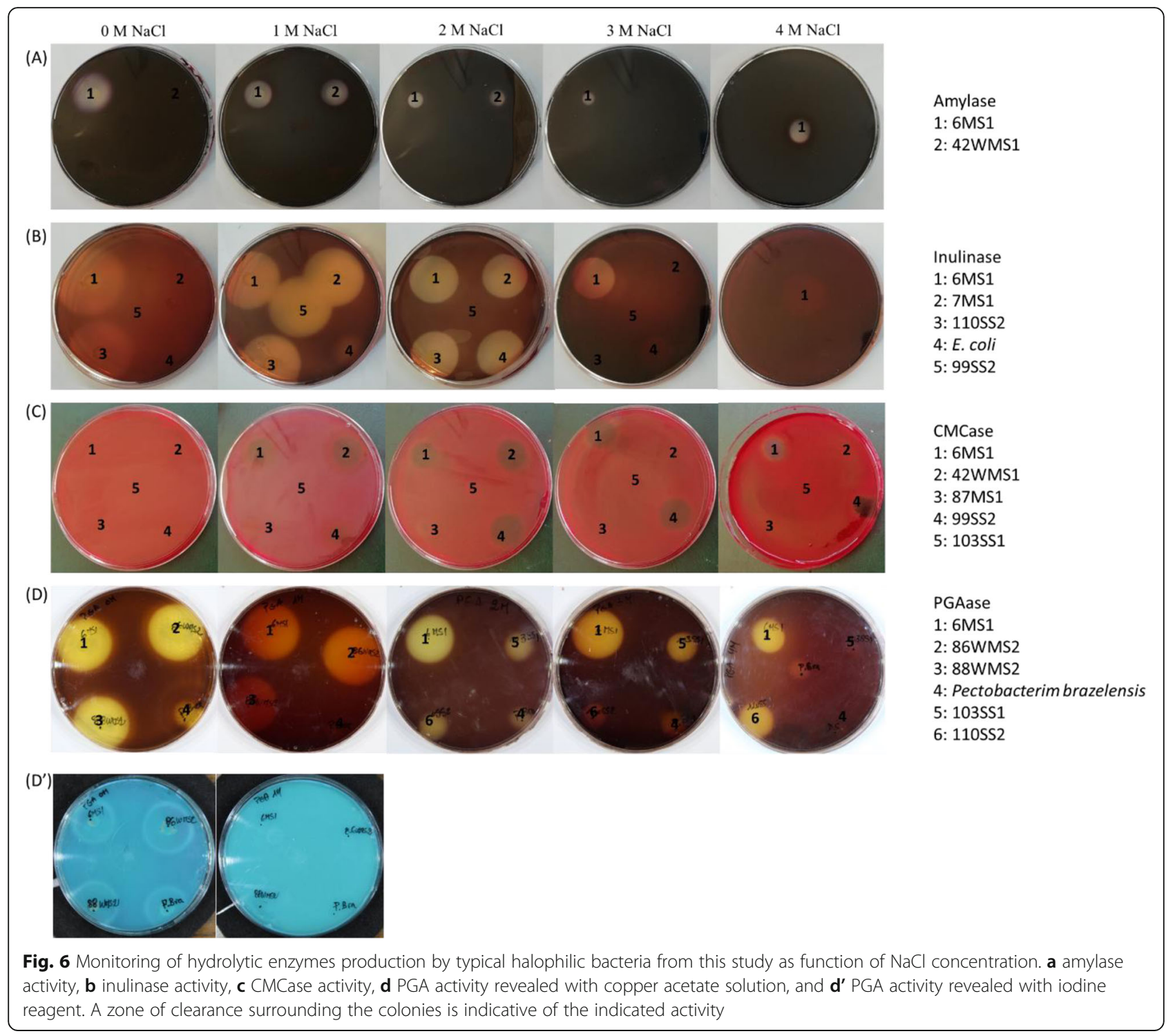

amylase, pectinase, and protease production. Extremely halophilic strains showed low cellulase production, moderate pectinase and protease, and high inulinase-degrading enzymes. The variation of enzyme activities for the same genera and species, especially for Bacillus and Staphylococcus, can also be explained by the wide diversity of physiological abilities (De Vos et al. 2012) and some minor factors like the evaporation from liquid cultures in media with high salinity that can lead to changes in salt concentrations with time.

\section{Conclusion}

This study allowed the isolation of a bacterial collection ranging from moderately to extremely halophilic bacteria. The subset of a collection from hypersaline environments in the pre-Rif region, Morocco, exhibiting hydrolase activity, was clustered into 26 genera. Our results relied mainly on varying $\mathrm{NaCl}$ composition within the isolation medium, but we believe that other isolation media might potentially generate different results. Data analysis and correlation from this study indicates the following:

1. Hypersaline environments harbor an important number of halophilic bacterial consortia, sharing different $\mathrm{NaCl}$ tolerance;

2. A large number of hydrolytic enzyme producers could be isolated frequently from hypersaline environments; and

3. The hydrolytic activities and efficiency correlate with the $\mathrm{NaCl}$ concentrations. 
Moreover, this study gives insight on the relationship(s) between hypersaline environments and culturable bacteria that they contain. This reveals a wide diversity of halophilic bacteria from terrestrial hypersaline environments, fortunate enough to correlate with data from marine microbiology, thanks to the occurrence of several species frequently isolated from marine environments. The promising enzymatic activities displayed by these strains in the experimental conditions are often correlated to salt concentrations allowing such strains to operate under harsh conditions.

\section{Supplementary information}

Supplementary information accompanies this paper at https://doi.org/10. 1186/s13213-020-01570-z.

Additional file 1: Figure S1. Location of the sampling region. Figure

S2. Images of the sampling settling pond of the three sites. Table S1.

Accession numbers of the designations type strains used as the closest neighbors as well as their range of $\mathrm{NaCl}$ concentration for optimal growth. ND: Not Determined.

\section{Acknowledgements}

The authors are thankful to Dr. Violetta Cavallei from the Al Akhawayn University for reviewing the English of the present paper. The authors acknowledge the technical support from The City of Innovation-Fez, Morocco. This work is supported by the University Sidi Mohamed Ben Abdellah (USMBA) for financial and technical support.

\section{Authors' contributions}

LBDK carried out the microbiological, chemical and biochemical studies, participated in the phylogenetic studies and drafted the manuscript.

JA carried the microbiological, chemical and biochemical studies, carried out the phylogenetic studies, performed the statistical analysis, drafted and proof read the manuscript. MEH participated in the manuscript drafting and its proof reading. KS participated in the manuscript drafting and its proof reading. All authors read and approved the final manuscript.

\section{Funding}

Not applicable.

\section{Ethics approval and consent to participate}

This article does not contain any studies with human or animal subjects.

\section{Consent for publication}

Not applicable.

\section{Competing interests}

The authors declare that they have no conflict of interest.

\section{Author details}

${ }^{1}$ Faculty of Sciences Dhar El Mahraz, Laboratory of Biotechnology, Environment, Agri-Food and Health, Sidi Mohamed Ben Abdellah University, Fez, Morocco. ${ }^{2}$ Pole of health, Euromed School of Engineering, Euro-Mediterranean University of Fez, Fez, Morocco. ${ }^{3}$ School of Science and Engineering, Laboratory of Biotechnology, Al Akhawayn University in Ifrane, Ifrane, Morocco.

\section{Received: 5 September 2019 Accepted: 23 April 2020}

Published online: 27 May 2020

\section{References}

Al-Rubaye MTS, Al-Musawi MHJ, Fakhari J, Hosseini M (2017) Screening and characterization of halophilic bacteria with industrial enzymes from Salt Lake Razazah, Karbala, Iraq. Biosci Biotech Res Asia 14(2):531-539 https://doi.org/ $10.13005 / \mathrm{bbra} / 2476$
Babavalian H, Amoozegar MA, Zahraei S, Rohban R, Shakeri F, Moghaddam MM (2014) Comparison of bacterial biodiversity and enzyme production in three hypersaline lakes; Urmia, Howz-Soltan and Aran- Bidgol. Indian J Microbiol 54(4):444-449. https://doi.org/10.1007/s12088-014-0481-9

Berrada I, Willems A, De Vos P, El Fahime E, Swings J, Bendaou N, Melloul M, Amar M (2012) Diversity of culturable moderately halophilic and halotolerant bacteria in a marsh and two salterns a protected ecosystem of Lower Loukkos (Morocco). Afr J Microbiol Res 6(10):2419-2434 https://doi.org/10. 5897/AJMR11.1490

Boone D. R, Castenholz RW, Garrity GM (2001) Bergey's Manual of Systematic Bacteriology. Volume one: the archaea and the deeply branching and phototrophic bacteria. Springer-Verlag, New York Berlin. https://doi.org/10. 1007/978-0-387-21609-6

Bouchotroch S, Quesada E, Del Moral A, Bejar V (1999) Taxonomic study of exopolysaccharide-producing, moderately halophilic bacteria isolated from hypersaline environments in Morocco. Syst Appl Microbiol 22:412-419 https://doi.org/10.1016/S0723-2020(99)80050-2

Bowman JP (2015) Shewanella. In: Whitman WB, Rainey F, Kämpfer P, Trujillo M, Chun J, DeVos P, Hedlund P, Dedysh S (eds) Bergey's Manual of Systematics of Archaea and Bacteria. John Wiley \& Sons, Chichester, UK, pp 1-22. https:// doi.org/10.1002/9781118960608.gbm01100

Bradford MM (1976) A rapid and sensitive method for quantitation of microgram quantities of protein utilizing the principle of protein-dye binding. Anal Biochem 72(1-2): 248-254. https://doi.org/10.1016/0003-2697(76)90527-3

De Lourdes MM, Pérez D, García MT, Mellado E (2013) Halophilic bacteria as a source of novel hydrolytic enzymes. Life 3(1):38-51. https://doi.org/10.3390/ life3010038

De Vos P, Garrity GM, Jones D, Krieg NR, Ludwig W, Rainey FA, Schleifer K-H, Whitman B (2012) Bergey's Manual of Systematic Bacteriology. Volume three: the Firmicutes. Second. Springer-Verlag, Dordrecht Heidelberg London New York. doi: https://doi.org/10.1007/b92997

Delgado-García M, Valdivia-Urdiales B, Aguilar-Gonzalez CN, Contreras-Esquivel JC, Rodriguez-Herrera R (2012) Halophilic hydrolases as a new tool for the biotechnological industries. J Sci Food Agric 92(13): 2575-2580. https://doi. org/10.1002/jsfa.5860

Demain A, Adrio J (2008) Contributions of microorganisms to industrial biology. Mol Biotechnol 38:41-55 https://doi.org/10.1007/s12033-007-0035-z

Di Donato P, Buono A, Poli A, Finore I, Abbamondi RG, Nicolaus B, Lama L (2018) Exploring marine environments for the identification of extremophiles and their enzymes for sustainable and green bioprocesses. Sustainability 11:149. https://doi.org/10.3390/su11010149

Dumorné K (2018) Biotechnological and industrial applications of enzymes produced by extremophilic bacteria (a mini review). Preprints, 2018010198. doi: 10.20944/preprints201801.0198.v1

Fox-Powell MG, Hallsworth JE, Cousins CR, Cockell CS (2016) lonic strength is a barrier to the habitability of Mars. Astrobiology 16(6):427-447

Gerhardt P, Murray RGE, Wood WA, Krieg NR (1994) Methods for general and molecular bacteriology. American Society for Microbiology, Washington. https://doi.org/10.1002/food.19960400226

Gohel HR, Contractor CN, Ghosh SK, Braganza VJ (2014) A comparative study of various staining techniques for determination of extra cellular cellulase activity on carboxy methyl cellulose (CMC) agar plates. Int J Curr Microbiol App Sci 3(5):261-266

Graf-Rosenfellner M, Cierjacks A, Kleinschmit B, Lang F (2016) Soil formation and its implications for stabilization of soil organic matter in the riparian zone. Catena 139:9-18 https://doi.org/10.1016/j.catena.2015.11.010

Hagihara B (1958) The enzymes, Volume 4. In: Boyer PD, Lardy H and Myrback K (eds). Academic Press Inc, New York, p 193

He Z, Zhou A, Baidoo E, He Q, Joachimiak MP, Benke P, Phan R, Mukhopadhyay A, Hemme CL, Huang K, Alm EJ, Fields MW, Wall J, Stahl D, Hazen TC, Keasling JD, Arkin AP, Zhou J (2010) Global transcriptional, physiological, and metabolite analyses of the responses of Desulfovibrio vulgaris Hildenborough to salt adaptation. Appl Environ Microbiol 76:1574-1586

Krieg NR, Ludwig W, Whitman WB, Hedlund BP, Paster BJ, Staley JT, Ward NL, Brown DR (2012) Bergey's Manual of Systematic Bacteriology. Volume 4: The Bacteroidetes, Spirochaetes, Tenericutes (Mollicutes) Acidobacteria, Fibrobacteres, Fusobacteria, Dictyglomi, Gemmatimonadetes, Lentisphaerae, Verrucomicrobia, Chlamydiae, and Planctomycetes. Springer Dordrecht Heidelberg London New York. doi: https://doi.org/10.1007/978-0-387-68572-4

Kumar S, Stecher G, Li M, Knyaz C, Tamura K (2018) MEGA X: molecular evolutionary genetics analysis across computing platforms. Mol Biol Evol 35(6):1547-1549 https://doi.org/10.1093/molbev/msy096 
Küster E, Williams ST (1964) Selection of media for isolation of Streptomycetes. Nature 202:928-929 https://doi.org/10.1038/202928a0

Lee SD (2008) Brevibacterium marinum sp. nov., isolated from seawater. Int J Syst Evol Microbiol 58:500-504. https://doi.org/10.1099/ijs.0.65099-0

Li AX, Guo LZ, Fu Q, Lu WD (2011) A sample and rapid plate assay for screening of inulin-degrading microorganisms using Lugol's iodine solution. Afr J Biotechnol 10(46):9518-9521 https://doi.org/10.5897/AJB11.1367

Lima RN, Porto AL (2016) Recent advances in marine enzymes for biotechnological processes. Adv Food Nutr Res 78:153-192. https://doi.org/ 10.1016/bs.afnr.2016.06.005

Liu C, Baffoe DK, Zhang M (2018) Halophile, an essential platform for bioproduction, Journal of Microbiological Methods, https://doi.org/10.1016/j. mimet.2019.105704

Michard A, Mokhtari A, Chalouan A, Saddiqi O, Rossi P, Rjimati EC (2014) New ophiolite slivers in the External Rif belt, and tentative restoration of a dual Tethyan suture in the western Maghrebides. Bull Soc Géol Fr 185(5): 313-328. https://doi.org/10.2113/gssgfbull.185.5.313

Mishra S, Behera N (2008) Amylase activity of a starch degrading bacteria isolated from soil receiving kitchen wastes. Afr J Biotechnol 7(18):3326-3331 https:// doi.org/10.5897/AJB08.582

Oren A (2015) Halophilic microbial communities and their environments. Curr Opin Biotechnol 33:119-124 https://doi.org/10.1016/j.copbio.2015.02.005

Ortega G, Laín A, Tadeo X, López-Méndez B, Castaño D, Millet O (2011) Halophilic enzyme activation induced by salts. Sci Rep 1:6 https://doi.org/10.1038/ srep00006

Quax WJ (2006) Bacterial enzymes. In: Dworkin M, Falkow S, Rosenberg E, Schleifer KH, Stackebrandt E (eds) The Prokaryotes, 3rd edn. Springer, New York https://doi.org/10.1007/0-387-30741-9_22

Ramos CP, Fernández-Garayzábal JF (2015) Sanguibacter. In: Whitman WB, Rainey F, Kämpfer P, Trujillo M, Chun J, DeVos P, Hedlund B, Dedysh S (eds) Bergey's Manual of Systematics of Archaea and Bacteria. John Wiley \& Sons, Chichester, UK, pp 1-9. https://doi.org/10.1002/ 9781118960608.gbm00137

Remonsellez F, Castro-Severyn J, Pardo-Esté C, Aguilar P, Fortt J, Salinas C, Barahona S, León J, Fuentes B, Areche C, Hernández KL, Aguayo D, Saavedra CP (2018) Characterization and salt response in recurrent halotolerant Exiguobacterium sp. SH31 isolated from sediments of Salar de Huasco, Chilean Altiplano. Front Microbiol 9: 2228. https://doi.org/10.3389/fmicb.2018.02228

Rhoades JD, Kandiah A, Mashali AM (1992) The use of saline water for crop production. Food and Agriculture Organization of the United Nations (FAO), Rome.

Richards LA (1954) Diagnosis and Improvement of Saline and Alkali soils. U.S. Government Printing Office, Washington D.C. https://doi.org/10.1126/science. 120.3124 .800

Rodier J, Legube B, Merlet N (2009) Eaux naturelles, eau potable et réseaux, Analyse physico-chimique. In: Legube B, Merlet N (eds) L'analyse de l'eau Contrôle et interprétation, 10rd edn. Dunod, Malakoff. pp 5-539.

Rosselló-Mora RA, Caccavo F, Osterlehner K Jr, Springer N, Spring S, Schuler D, Ludwig W, Amann R, Vancanneyt M, Schleifer KH (1995) Isolation and taxonomic characterization of a halotolerant, facultatively iron-reducing bacterium. Syst Appl Microbiol 17:569-573 https://doi.org/10.1016/S07232020(11)80078-0

Simidu U, Kita-Tsukamoto K, Yasumoto T, Yotsu M (1990) Taxonomy of four marine bacterial strains that produce tetrodotoxin. Int J Syst Bacteriol 40(4): 331-336. https://doi.org/10.1099/00207713-40-4-331

Singh R, Kumar M, Mittal A, Kumar MP (2016) Microbial enzymes: industrial progress in 21st century. 3 Biotech 6: 174. https://doi.org/10.1007/s13205016-0485-8

Torregrosa-Crespo J, Galiana CP and Martínez-Espinosa RM (2017). Biocompounds from Haloarchaea and their uses in biotechnology, Archaea - New Biocatalysts, Novel Pharmaceuticals and Various Biotechnological Applications, Haitham Sghaier, Afef Najjari and Kais Ghedira, IntechOpen, doi: https://doi.org/10.5772/intechopen.69944

Trujillo ME, Goodfellow M (2015) Brevibacterium. In: Whitman WB, Rainey F, Kämpfer P, Trujillo P, Chun J, DeVos P, Hedlund B, Dedysh S (eds) Bergey's Manual of Systematics of Archaea and Bacteria. John Wiley \& Sons, Chichester, UK. https://doi.org/10.1002/9781118960608.gbm00062

Turner S, Pryer KM, Miao VP, Palmer JD (1999) Investigating deep phylogenetic relationships among cyanobacteria and plastids by small subunit rRNA sequence analysis. J Eukaryot Microbiol 46(4):327-338. https://doi.org/10. 1111/j.1550-7408.1999.tb04612.x
Ventosa A, Arahal DR (2009) Halophily (halophilism and halophilic microorganisms). In: Gerday C, Glansdorff N (eds) Extremophiles. EOLSS, Oxford, United Kingdom

Ventosa A, de la Haba RR, Sánchez-Porro C, Papke RT (2015) Microbial diversity of hypersaline environments: a metagenomic approach. Curr Opin Microbiol 25: 80-87 https://doi.org/10.1016/j.mib.2015.05.002

Vera-Gargallo B, Ventosa A (2018) Metagenomic insights into the phylogenetic and metabolic diversity of the prokaryotic community dwelling in hypersaline soils from the Odiel Saltmarshes (SW Spain). Genes 9(3):152. https://doi.org/10.3390/genes9030152

Vogel BF, Jorgensen K, Christensen H, Olsen JE, Gram L (1997) Differentiation of Shewanella putrefaciens and Shewanella alga on the basis of whole-cell protein profiles, ribotyping, phenotypic characterization, and $16 \mathrm{~S}$ rRNA gene sequence analysis. Appl Environ Microbiol 63(6):2189-2199

Whitman W, Goodfellow M, Kämpfer P, Busse H-J, Trujillo M, Ludwing W, Suzuki K-I, Parte A (2012) Bergey's Manual of Systematic Bacteriology, Volume 5: the Actinobacteria. Springer-Verlag, Dordrecht Heidelberg London New York. Doi: https://doi.org/10.1007/978-0-387-68233-4

Yoon J-H, Kim B-C, Park Y-H (2015) Planomicrobium. In: Whitman WB, Rainey F, Kämpfer P, Trujillo M, Chun J, DeVos P, Hedlund B, Dedysh S (eds) Bergey's Manual of Systematics of Archaea and Bacteria. John Wiley \& Sons, Chichester, UK, pp 1-6. https://doi.org/10.1002/9781118960608.gbm00562

\section{Publisher's Note}

Springer Nature remains neutral with regard to jurisdictional claims in published maps and institutional affiliations.

\section{Ready to submit your research? Choose BMC and benefit from:}

- fast, convenient online submission

- thorough peer review by experienced researchers in your field

- rapid publication on acceptance

- support for research data, including large and complex data types

- gold Open Access which fosters wider collaboration and increased citations

- maximum visibility for your research: over $100 \mathrm{M}$ website views per year

At BMC, research is always in progress.

Learn more biomedcentral.com/submissions 